\title{
Violence Against Women as a Human Rights Issue
}

\author{
Diana Bronson
}

I would like to try to unpack the slogan "women's rights are human rights" by looking specifically at the issue of violence againstwomen. I want to underline some of the theoretical and methodological issues-which of course have very practical and even life-and-death implications-involved in trying to see women's rights as human rights.

What do we mean when we say women's rights are human rights? This slogan is being used by different people and different groups to mean different things. In its most limited interpretation, we are saying merely that women are human and that they deserve the same rights as men. In a more expansive interpretation, we are saying that what we traditionally think of as women's rights-issues thatfeminists have raised, such as reproductive choice, violence or pornography-are fundamentally hu-

Committee on the Status of Women to the Conservative government in Canada, and the range is even broader if we look at the international picture. This is not necessarily a negative thing, but it is something of which we should all be aware.

Ihave been asked to address the issue of violence against women as a human rights issue, and I will try to do so by looking at the issue of domestic violence. I draw heavily on the arguments made by Dorothy Thomas andMichele Beasley in a recent issue of the Human Rights Quarterly, ${ }^{2}$ and I recommend that article to anyone who wants a more thorough examination of the issue.

First of all, I think it is important to have a human rights discourse that can lay some kind of claim to universality. Noteverything that is undesirable can all of a sudden become a human rights is-

\section{Developed from Western political theory, international human rights law concentrates exclusively on acts for which the state can be held accountable.}

man rights issues. Not surprisingly, the latterinterpretation is considerably more controversial and can even pit the women's rights advocates against some more traditionalhuman rights and/orcivilliberties groups. It is interesting to note that, in the document the new administration in the U.S. has put out for the world conference on human rights, there is an emphasis on the rights of women, including "battering in the family, rape, female infanticide, honour killings and dowry murder" but no mention is made of reproductive rights. ${ }^{1}$ There is a very wide spectrum of voices chanting this slogan-from the National Action

Diana Bronson is an information officer at the International Centre for Human Rights and Democratic Development, Montreal. The views expressed in this article are her own. sue. Human rights discourse gains its legitimacy and therefore its power precisely by claiming that all human beings share the rights that it enumerates and that there is some kind of international legitimacy in the discourse. That legitimacy cannot be taken for granted, but, relatively speaking, a human rights discourse does quite well in comparison to feminism. As Hilary Charlesworth from Australia has argued, human rights provides a significant vocabulary for women because it is recognized by the powerful.

The challenge for women is therefore to use the tools that have already been developed to defend their own interests. We know these tools have been developed by men; they suit men's needs and speak to male realities. You will recall the case last year of a 14-year-old Irish girl who was raped and became pregnant.
The Irish government refused to allow her to go to Britain to obtain an abortion, and the injunction it obtained against her was eventually overturned. Women's groups argued that her right to control her own body had been violated, and while I don't have any special insight in the decision-making process, I think it was useful that human rights groups could intervene on her behalf, pointing to a specific article in the Universal Declaration of Human Rights that guarantees freedom of movement. Unfortunately, feminist arguments do not carry the same weight internationally: freedom of choice is not guaranteed in the International Bill of Human Rights. It is useful to use the language of human rights to speak to female experiences of oppression even if theinternational instruments do not deal directly with those experiences: clitoridectomy can be understood as a form of torture, domestic violence as an assault on the security of the person, and restrictions on travel as violations of freedom of movement. Human rights can give women a powerful language to express their opposition to their secondclass status.

Developed from Western political theory, international human rights law concentrates exclusively on acts for which the state can be held accountable. In recent history, this has come to mean not only acts which are committed by the state, but acts which the state fails to prosecute systematically.

International human rights law, while recognizing that the rights proclaimed in its various treaties apply equally to women and to men, is basicallygender neutral-with theexception of the convention to Eliminate all Forms of Discrimination Against Women, which incidentally does not mention violence at all.

That is to say, international human rights law ignores the fact that men and women do not have the same access to the public sphere and that the most 
persistent violations of women's life, liberty and security of the person occur in the private sphere. This creates a problem in proving that the state is accountable, the dominant ethos being until very recently that the state has no business in the bedrooms of the nation and that every man is a master in his own home.

As refugee advocates have recently argued in this country, and as is recognized in the new guidelines on genderrelated persecution, the state can in fact be considered accountable for failing to act to protect women from domestic violence. The Washington-based Human Rights Watch group was the first human rights group, to my knowledge, to unequivocally and explicitly recognize that domestic violence was a human rights woman's complaint, and women know that it is not worth the effort.

Human rights advocates have, over the years, developed rigorous methodologies for documenting abuses. Objectivity and neutrality are perceived as being absolutely essential to any credible human rights report. Yet the orientation that feminist scholarship has adopted over the last decade has taken the opposite direction, and it offers a rather profound critique of objectivist epistemologies and methodologies. I think this is a key problem that we will be forced to address if the human rights movement is to take women's rights seriously. Perhaps human rights groups and refugee documentation centres will have to be satisfied with more anecdotal,

\section{International human rights law ignores the fact that men and women do not have the same access to the public sphere and that the most persistent violations of women's life, liberty and security of the person occur in the private sphere.}

issue. In its Brazilian report, ${ }^{3}$ the group showed that the state was complicit in the crime because it failed to prosecute it equally to other crimes and to guarantee women the fundamental civil and political right to equal protection before the law without regard to sex. Furthermore, not every act that the state fails to prosecute becomes a human rights issue; it only becomes one when the reason the state fails to prosecute is discrimination on the grounds of race, religion, sex and so on.

This report marks a very fundamental shift in the dominant paradigm of human rights theory. While international human rights law has recognized the state obligation to punish human rights violations by private actors, this report takes it one step further; it takes it more clearly into the domestic sphere and, at the same time, makes human rights relevant to women's experience.

The difficult part in a court of law or at a refugee hearing is proving that the state is accountable in the sense defined above. How can anyone document that a crime such as wife abuse is widespread and non-prosecutable if no one is keeping statistics or documenting abuse? In many countries, police will not record a qualitative evidence, and women's groups will have to start using the methodologies and gathering the kind of traditional documentation that is needed if they are to be able to effectively use the international mechanisms of human rights protection. I think there has to be some movement in both directions. So far, women's and human rights groups are not really using the same language; but that is beginning to change.

The challenge for women is to use the language and mechanisms of international human rights law in a way that makes it relevent to their experience. The challenge for the human rights movement is to start taking the violations of women's rights as seriously as the violations of men's rights. Women must use the paradigm that exists already and begin to forge a new one for the realities that the old language of human rights still cannot address.

\section{Notes}

1. New York Times (May 9, 1993).

2. Dorothy Q. Thomas and Michele E. Beasley, "Domestic Violence as a Human Rights Issue," Human Rights Quarterly 15(1993): 36-62.

3. "Criminal Injustice: Violence Against Women in Brazil," Americas Watch (New York: Human Rights Watch, 1991).

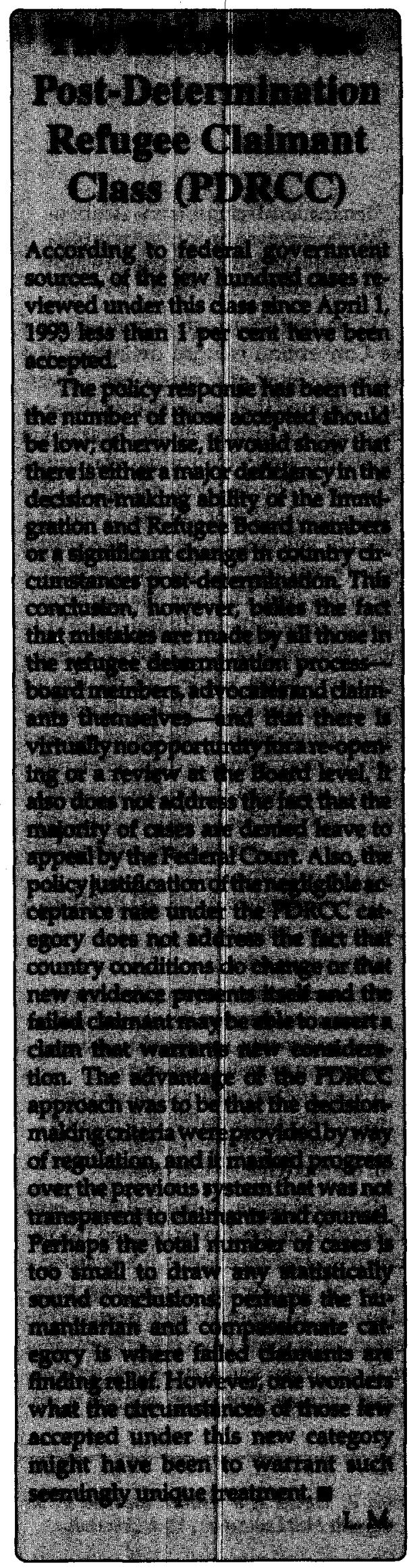

